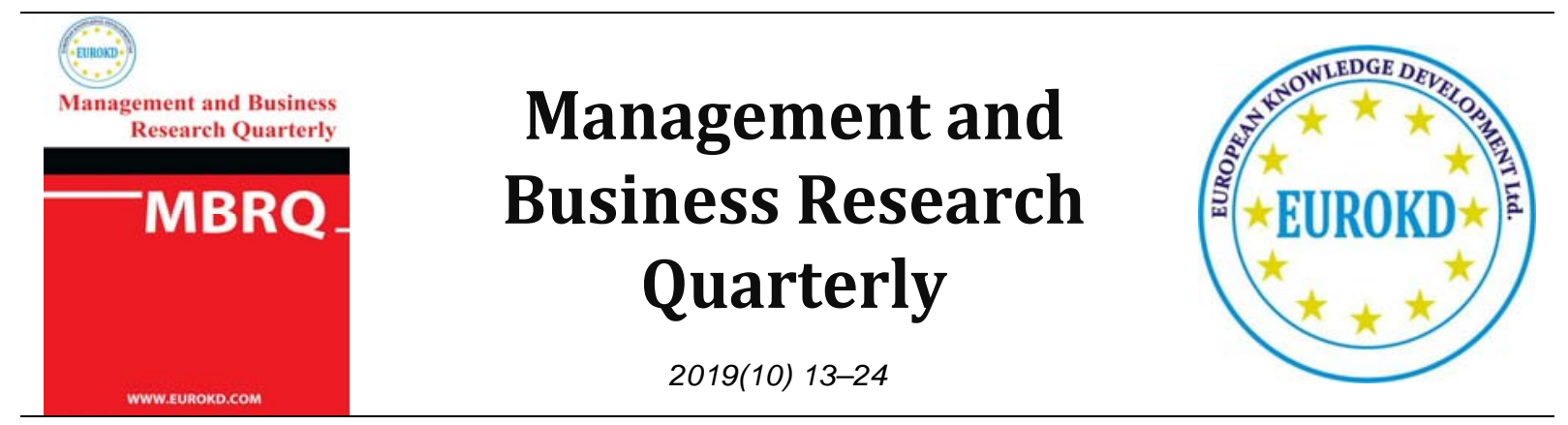

\title{
Kinetic Leadership: Decision-making in Action
}

\author{
Jeffrey Darville \\ Assistant Professor Dr. Jeffrey Darville, American University in the Emirates, Dubai, UAE
}

Received 7 May $2019 \quad$ Accepted 27 June 2019

\begin{abstract}
Kinetic leadership: Decision-making in action provides a theoretical perspective derived from a model of leadership for top management teams in decision-making processes. This model is based on research and literature on groups, teams, decision-making, conflict and leadership. The results of scholarship on leadership and decision-making have influenced management and administration over the last 50 years. This research framework will focus on the relationships between decisionmaking and conflict in leadership for top management teams through group dynamics in terms of procedural rationality and collaboration. It will trace the progress of decision-making as a social construct and key leadership skill. The impact of leadership on decision-making is highly significant for individuals, groups, and organizations as future research in this area is proposed.
\end{abstract}

Keywords: Leadership Theory, Top Management Teams, Decision-Making, Conflict, Procedural Rationality, Intuition, Participation, Collaboration.

\section{Introduction}

Decision-making in leadership has been examined through the lens of conflict and small groups to aid management practice and education. Individuals need to improve their personal decisionmaking ability. Organizations need to enhance their ability to utilize the decision-making capacity of numerous people. And institutions of higher learning need to teach students how to do both. Eisenhardt and Zbaracki (1992) proposed "a research agenda that emphasizes a more realistic view of strategic decision makers and decision making, and greater attention to normative implications, 
especially among profit-seeking firms in global contexts." They essentially reiterate their own research into bounded rationality (Simon, 1991), power politics (Pfeffer, 1992) and the garbage can model (Cohen, March, \& Olsen, 1972) of strategic decision-making as a future aim for scholarship. However, the essential direction of their agenda into decision-making was picked up by others. Research that influences education will inform practice. Over the last 30 years many studies have aided our apprehension of decision-making as a construct in leadership.

When considering how leadership effects management of organizations it is important to make a distinction between leadership and management. Leadership is a relationship. Leadership is not a position or title. "Leadership is an influence relationship among leaders and followers who intend real changes that reflect their mutual purposes" (Rost, 1993). This means that leaders participate in leadership with followers. It is a reinforcing pattern where both members of this dynamic benefit from the exchange of ideas, actions, goals, and interests. Peter Drucker wrote (2012) "management is the work that is specific to modern organization and makes modern organization perform." Management theory began with Henri Fayol and his taxonomy of management functions which have been distilled over the decades to variations of planning, organizing, directing and controlling (Fayol, 1909). While leadership can be seen as synonymous with directing or influencing, leadership skills applied to interpersonal interactions are at work in developing and communicating all of the various roles managers have including the planning, organizing and controlling process.

To consider how decisions are made, plans developed and implemented it is helpful to review the levels at which leadership is applied. Leader-Member exchange (LMX) provided an advancement of leadership theory by addressing the level of analysis explicitly, focusing on domain of leadership as the relationship between leaders and followers studied as dyadic pairs (Graen \& Uhl-Bien, 1995). This has been extended in rich studies which address the differential relationships that occur within small groups. It has been hypothesized that understanding small group theory including the psychology, communication, and organizational behavior of small groups is necessary for the development of decision-making and leadership theory. Theorists and researchers have described general stages of group development (Tuckman, 1965; Tuckman \& Jensen, 1977), offered models for this process (Chang, Duck, \& Bordia, 2006; Gersick, 1988; Wheelan, 1994), and applied group development theories and models to work teams (Kozlowski, Gully, Nason, \& Smith, 1999). These models include aspects of conflict in the development of group identity and cohesion. In cases where groups are making decisions, the development of norms that support high quality decisions is essential to the group's success.

This study operates on the meso-organizational level of analysis dealing with work groups. Work teams are interdependent from other groups and members share the responsibility for specific achievements in the organization (Forsyth, 2009). Team leadership is a form of influence where team members move together towards achieving their goals, formal and informal leaders direct and coordinate action and resolve differences (Bass \& Stogdill, 1990; Fiedler, 1995; Wheelan, 1994). According to Thompson (2013), unlike groups, teams have shared goals, interdependencies, limits, decision-making powers, and the context of social systems. Teams are an integral part of many organizations. In many cases, it is the main organizational unit for teams, not individuals, to accomplish their work and drive improvements (Avolio, Jung, Murry, \& Sivasbramaniam, 1996). 
Organizational leaders often make decisions in the context of a steering committee, leadership council, executive suite, or top management team. The team is the epicenter of modern organizational leadership and research (Day, Zaccaro, \& Halpin, 2004; Forsyth, 2009). Collaboration and teamwork solve many problems more effectively and quickly than individuals (Ulrich, 1998). Team development and effectiveness has been extensively researched in leadership studies as the source and focus of leader outcomes (Pearce \& Sims Jr, 2002; Pearce, Yoo, \& Alavi, 2004; Perry, Pearce, \& Sims Jr, 1999). The quality of team leadership directly affects the outcome of decision making and performance (Avolio et al., 1996; Hollenbeck et al., 1995; Salas et al., 2008; Stewart \& Manz, 1995). Therefore, how leaders effect decisions and how these decisions are implemented is a significant measure of leader influence.

How decisions are made is defined by the group processes that are at work in any team. Leaders set the tone for the group. The Tanenbaum-Schmidt (1973) decision-making and leadership spectrum gives an early description of autocratic and democratic leadership styles. A laissez-faire style, or fully delegating authority to others, is an absence of leadership that may be a developmental track to encourage others to lead but fails to meet the definition of leadership in practice. Likewise, the Vroom-Yetton (1973) decision tree took these categories and applied them to a framework based on a series of questions about the participation levels and conditions that required or permitted certain decision-making approaches. Both in concert remain a useful paradigm for understanding the approach that leaders take toward their subordinates. While these early theories of leadership over emphasized the role of the leader in decision-making the models that were produced have bearing on strategic decision-making in small groups as the most pronounced situation where executives influence the direction of their organization.

Every significant leadership interaction that produces results is proceeded by a decision. If effective leaders make high quality decisions, then cultivating systems and processes that produce better decisions is incumbent on all organizations. One area of decision-making and leadership that has received substantial interest in theoretical and empirical studies is the use of ethical processes (M. E. Brown \& Treviño, 2003; M. E. Brown, Treviño, \& Harrison, 2005; Trevino, 1986). Ethics are standards that are independent of leadership, therefore the practice of leadership should not be conflated with the social norms, values and duties used to judge human behavior (Ciulla, 2014).

However, the ethical quality of decisions is a necessary but insufficient base to establish effectiveness. McFarlin and Sweeney (1992) established a difference between procedural justice, the process whereby an employee evaluation was reached, and distributive justice, the fairness of the results of evaluations. This distinction extends to various judgement and decisions. If an unethical decision accomplishes the goal of an organization, it may be deemed effective even as it exposes individuals and the group to greater risks. This exposes the ends versus the means argument and individualized Machiavellian tendencies in decision-making (Sweeney \& McFarlin, 1993). Therefore, leadership must be able to balance the interests of a group while emphasizing ethics as a needed component of reasonable quality in the decision-making process.

This framework is based on prior research conducted on higher education leadership teams and begins to delineate between the process and results of decision-making (Darville, 2018). Kinetic 
leadership is active leadership that builds relationships, influences, and motivates other people to self-development and achieve organizational goals by helping teams make good decisions and implement strategy. The process should include procedural rationality which is characterized as an attempt to collect all the necessary information to form expectations about possible alternatives while using these options to make the final decision (Dean \& Sharfman, 1993). In developing this instrument, procedural rationality was found to be a valid construct with a Cronbach's alpha of .80. Therefore, this scale of rational group processes has been used to assess the manner in which groups make decisions. The five variable items used in the study were drawn specifically from the Herbert Simon and his observations about bounded rationality (1991). This process must consider more than data alone to buffer decisions with moral and intuitive insights.

\section{Literature Review}

Decision-making ability is one of the most important skills leadership (Jenkins, 2012). Researchers have studied decision-making at multiple levels; it has been researched as an economic construct, a social process, and as a component of leadership (Fisher \& Ellis, 1980; Lewin \& Gold, 1999; Sanfey, Rilling, Aronson, Nystrom, \& Cohen, 2003). Differences in the decision-making processes used by individuals in leadership roles will create a cultural norm within the group where conversations about decisions take place. Building on non-rational decision-making model from behavioral decision theory, recognizing biases and using heuristics can be an effective and efficient guide to decision-making and associated with innovativeness. (Busenitz \& Barney, 1997).

Additionally, and separately, a variety of benefits are derived from rational processes where leaders who manage conflict and promote rationality in strategic decision-making are more successful in the implementation of plans (Kathleen M. Eisenhardt, Kahwajy, \& Bourgeois III, 1998; Ensley, Pearson, \& Pearce, 2003; Thomas, 1988). Therefore, a model for effective decision making that balances both the non-rational and reason-based elements of decision-making is needed. While decision-making can be viewed as the process of decision makers exercising choice to solve a problem or a series of problems others view decision-making and problem solving as more distinct (Ackoff, 1978). This view conflates problem solving with decision-making. Problem solving however is more discrete than decision-making and focuses on action to resolve an issue.

Decision-making in an organization is a complex process that includes a wide variety of actors and agents who have many responsibilities and interests. The intersection of strategy and decisionmaking takes place where leadership teams develop plans and enact them throughout the firm. Research that focuses on strategic decision models, biases in decision making, and upper echelon teams developed the limitations and responsibilities of leaders in guiding an organization toward its goals (Schwenk, 1995) "Top management teams make strategic decisions, and the products of their decision-making influence organizational performance (Amason, 1996)." This research indicates that the role of conflict in group decision-making effects quality, consensus, and affective acceptance.

An important distinction in decision theory is the difference between the decision process and outcomes of individuals and groups. Group decision making is an inter-group process that select a course of action among several possibilities (Sowell, 1996). In many cases, the information needed 
to make decisions is decentralized, requires a great deal of expertise to interpret and the consequences of crucial decisions are profound. The individuals do not carry out the plan directly, but a decision is disseminated across the organization. An event of decision-making can be narrowly defined however the impact of leadership is diffuse.

Many experiments and studies have attempted to control for rationality or express the impact of it in decision making. Process accountability has been manipulated to understand the group's ability to share information and make quality decisions (Scholten, Van Knippenberg, Nijstad, \& De Dreu, 2007). This has been used to show how teams make decisions, an approach which aligns with procedural justice conceptually, is an important indication of acceptance. This acceptance can then be correlated with the thoroughness with which the decision was scrutinized and vetted.

Each individual has a preferred decision-making style; this is the manner in which they comfortably make decisions. The GDMSI describe decision-making preferences as rational, intuitive, spontaneous, avoidant and dependent. Avoidant and dependent individuals in groups are not actively participating or concluding independently of others during the decision-making process. The spontaneous style is akin to more emotional or impulsive decision-making. The rational and intuitive preferences are the most active and engaged forms of decision-making in the GDMSI (Scott \& Bruce, 1995). These final two styles, rational and intuitive are related to the two cognitive systems that were identified in behavioral economics and explicated more recently (Kahneman, 2011). This is true whether or not these represent bipolar opposites or, more likely, the most active variables in a multi-dimensional construct. The relationship between rationality and intuition is the needed focus of much of the research being developed in leadership and strategic decision-making.

From a practical standpoint, decisions rarely occur within a purely rational, logical, and reasonbased process. While rationality affects group decision making, one should not expect to use only a rational criterion as a measure of decision quality. Instead, the structure of decision making is understood as a complex event flow (McCall \& Kaplan, 1989). Studies have shown the impact of group processes on team decision-making. Bruine de Bruin (2007) correlated specific elements of GDMSI (Generalized Decision-Making Style Index) with decision quality. They found that the rational style $(r=0.22, p<0.001)$ was significantly correlated with the quality of the decision. Both rational and intuitive decision makers are satisfied with their individual outcomes, rational $(\mathrm{r}=.21$, $\mathrm{p}<.001)$ and intuitive $(\mathrm{r}=.16, \mathrm{p}<.001)$, however subjective feelings about the outcome does not directly relate to a plan's success.

The way that these decision-making styles interact is an important aspect of group decisionmaking where each member brings their own set of experiences and assumptions to bear on the dynamics that take place. Rationality has been operationalized as expressions of reason and logic. It was found that the GDMSI item for rationality did not reach alpha reliability in a recent study of academic administrators (Darville, 2018). And, intuition is best understood as a form of crystalized experience that can be viewed as an interaction between thinking and feeling, where emotion both guides and reflects the individual's thought process. This is different than affective decisions which are more attune to "trusting your gut," instinct, or reactions based on emotion alone. 
Cognitive shortcuts can be useful, however individuals who take actions based on instincts or heuristics alone often fall prey to cognitive biases (Tversky \& Kahneman, 1974). Since leaders are people, we can say that they use both intuitive and rational decision-making. Leadership qualities related to decision-making style are informative in terms of how groups make decisions. Understanding bounded rationality is a helpful theoretical limitation on the types of decisionmaking that is taking place (Gigerenzer \& Goldstein, 1996; Gigerenzer \& Selten, 2001; Kahneman, 2003; H.A. Simon, 1997; Herbert A. Simon, 1991). How biases and preferences effect group decision-making, especially at the executive, strategic and organizational level, is yet to be fully explored.

Another factor in decision-making is that conflict occurs when one person's actions or beliefs are unacceptable and resisted by one or more group members (Forsyth, 2009). It is a microcosm of creative destruction and negotiation at a personal level. It is also part of the process of generating ideas, making decisions, and implementing them. Mumford (2003) describes leadership as drawing from shared thinking in the group to spur on greater creativity. Working through conflict may be necessary for a group to become a more creative, highly functioning and successful team. However, mistaking affective conflict for cognitive conflict or avoiding conflict altogether may derail group development, decision-making, the overriding strategic needs, and interests of the organization (Amason, 2010).

Variables associated with individual decision styles can be associated with conflict types. More discussions and debates about ideas and less political ranker in decision-making is one of the best indications of decision quality, buy-in, and execution when the decision-making process was expressed as multidimensional organization and controlled for rationality (Kieser \& Koch, 2008). In these studies, rationality promotes information exploration, better information exchange, and an increase in the amount of repeated information. It then follows that decision-making processes and effectiveness are mediated by procedural rationality, which is considered to be predictable and understood steps in events such as conferences (Dean \& Sharfman, 1993). Team leaders who think of themselves as rational and reasonable will likely demonstrate this in the group's decision-making process and may increase conflicts about ideas.

Conflict is "a process that begins when an individual or group perceives differences and opposition between itself and another individual or team about interests and resources, beliefs, values, or practices that matter to them" (De Dreu \& Gelfand, 2008, p. 6). There are two primary dimensions of conflict, cognitive and affective (Amason, 1998). Affective conflict occurs when team members disagree over issues that are personal and emotional in nature. It can be referred to as interpersonal or relationship conflict. Cognitive conflict occurs when teams discuss and debate various preferences and opinions about their options, alternatives, tasks or decisions. It can be referred to as idea-based or task conflict.

Affective conflict hinders decision-making by creating animosity and distracting team members from the work at hand (Jehn, 1994, 1995; Simons \& Peterson, 2000). Cognitive conflict encapsulates debates that promote better decision-making by forcing teams to accommodate and synthesize multiple points of view (Schweiger, Sandberg, \& Rechner, 1989). A moderate amount of cognitive conflict is beneficial and therefore it appears to have a curvilinear relationship with 
decision quality and innovation (Jehn, 1995). Affective conflict has a negative relationship with decision quality; however, cognitive and affective conflict can be coincidental. Thus, a leadership team that engages in conflict generally may be perceived as less cohesive by team members even as the task production and decision quality increases.

To establish how decisions are made it is helpful to return to one of the founding views on decision-making and leadership. The Vroom-Yetton Model (1973) is called a normative leadership theory; however, it is more useful as a conceptual model for decisions rather than a guide. This decision-tree emphasizes how much participation from followers is needed or should be included in the decision-making process. The model is based on the need and expectation for high quality decisions. The outcomes and recommendations are decision approaches that range from autocratic to group-focused. However, it is unlikely that managers will use this model as method for determining which decision style to use. Rather research should describe how teams make decisions in practice and then determine the best point for a leader to intervene and positively impact the decision outcome to galvanize teamwork.

Consensus building is part of leadership and the natural negotiation that takes place in teams. Consensus is a synergy between ideas that produces a mutual agreement where all legitimate concerns of individuals have been addressed to the satisfaction of the group (Saint \& Lawson, 1994). Leaders, formal and informal, should test for consensus; if a proposed course of action is not approved by members, why not? This requires a better definition of consensus and conflict in the way that cooperative and collaborative behaviors produce the results organizations desire. Research that correlates various forms of teamwork to the dynamic use of cognitive conflict will bear greater benefits for management (Amason, 1994, 1995). The goal of this scholarship is to help members of teams to make their case, analyze data and evidence, and make higher quality decisions.

High velocity decision-making requires clarity and decisiveness. A manager who must make a decision quickly may sacrifice the ability to make the best decision utilizing a form a satisficing to resolve a crisis (Simon, 1997). In general, the person who will make the ultimate decision should lead the decision-making process. Yet, many roles exist in a team that take on various leadership qualities at different times (Li, Mirmirani, \& Ilacqua, 2009). Status and trust are balanced by individual members as they walk the line between being a "yes-man" or red hat disruptor (Hutzschenreuter \& Kleindienst, 2006). An easy way out is to offer and gain cheap approvals, however many teams need to encourage critical thinking that breaks down and builds up arguments to support high quality decisions. This is the subject of the following study.

\section{Methods and Limitations}

This study builds a decision-making model that is based on exploratory research in small group leadership at colleges. It begins to build a theoretical framework which aims to use the outcomes of research to describe aspects of Kinetic Leadership as a recommendation for Top Management Teams making strategic decisions. The analysis of the four variables for use in the model are presented as partially explanatory given the following assumptions, limitations, and boundary conditions. 
Limitations and delimitations are related to the theoretical and exploratory nature of the study. This study surveyed individuals who are identified as part of a work team in the president's cabinet of a college administration. A nonrandom sample of adults in work teams were selected for this study based on their availability to the researcher (Dattalo, 2008). The sample of 48 participants is small and not representative of the population or generalizable to other situations.

The instruments focus on the following four variables. The Intragroup Conflict Scale (Amason, Thompson, Hochwarter, \& Harrison, 1995; Jehn, 1994) provided subscales for (a) cognitive and (b) affective conflict types. Collaboration is based on behaviors related to cooperation in team decisionmaking (Alexander, 2000; Carson, Tesluk, \& Marrone, 2007). Collaboration is a measure of distributed or shared leadership where team members rely on one another, build trust, and share information for mutual understanding (Huxham \& Vangen, 2000; Wood, 2005). Procedural rationality is a measure of a group's adherence to a logical decision-making process in a team setting (Dean \& Sharfman, 1993; Elbanna \& Child, 2007). Where rationality as a process condition in planning "... provides grounds ... for acting on decisions" (Brown, 1988, pg. 226). This subscale captures group decision-making behaviors that support a rational process.

The boundary conditions for this study are based on the types of teams analyzed and the context of their decisions. The statistical power was limited, and control variables were not included. Data was collected from only eight groups and did not control for group differences. Future studies may develop this model with other variables and assess the impact of individual preferences on perceptions of conflict within the group when controlling for group differences. While group dynamics will influence other team member's thinking and expressions, this study only focused on individual level variables. It is likely possible that team members conform their decision-making style, observations and perceptions of conflict influence the preferences and actions of others in the group. Further research is needed to examine these areas, expand the sample and extend this study into other domains of management. The following conclusions provide a tentative link to the theoretical model that is being proposed.

\section{Findings and Conclusions}

Kinetic leadership is a process of proactive and thoughtful action based on a wholistic and strategic decision-making process. It focuses on managing collaborative behaviors while inviting a certain level of conflict. As this model is developed and proposed for future use and research the relationships between rationality and collaboration become clearer. Additionally, this model begins to outline the conditions where cognitive and affective conflict may increase or decrease thereby providing insight into the leadership behaviors that are most effective when seeking the highest quality and innovative decisions to produce the necessary strategies and plans to achieve ambitious goals. The following results indicate that collaboration decreases conflict and procedural rationality does not increase it.

Table 1. Bivariate simple linear regression models

\begin{tabular}{lccc}
\hline Response Variable & Explanatory Variable & $\boldsymbol{b}$ & $\boldsymbol{R}$ \\
\hline Cognitive & Collaborative & -1.45064 & $0.3855^{* *}$ \\
\hline
\end{tabular}




\begin{tabular}{lllc} 
Affective & Collaborative & -1.970129 & $0.4982^{* * *}$ \\
\hline Cognitive & Procedural Rationality & -.0391211 & 0.0374 \\
\hline Affective & Procedural Rationality & -.1194935 & 0.1389 \\
\hline
\end{tabular}

Note: b: standardized slope, $\mathrm{n}=48,{ }^{* *} \mathrm{p}<0.01 * * * \mathrm{p}<0.001$

Of these analyses, two tests produced highly significant relationships. As observations of collaborative decision-making increased, individual reports of both cognitive and affective conflict decreased. However, observations of procedural rationality were not significantly linked to either observations of cognitive or affective conflict. This process requires further study. Leaders who wish to create more innovative outcomes and higher quality strategic decisions need to foster a level of cooperative rivalry in their team where the desire for collaboration does not preclude the necessary cognitive conflict that will produce the desired results (To, Kilduff, et. al., 2018). This is the nature of Kinetic Leadership; it encourages action by challenging people and allowing disagreement while maintaining and encouraging the energy and input of participants through positive reinforcement of the purpose and goals of the team members and organization.

\section{References}

Ackoff, R. L. (1978). The Art of Problem Solving Accompanied by Ackoff's Fables. Retrieved from https://dspace.creighton.edu/xmlui/handle/10504/78300

Alexander, E. R. (2000). Rationality revisited: Planning paradigms in a post-postmodernist perspective. Journal of Planning Education and Research, 19(3), 242-256.

Amason, A. C. (1996). Distinguishing the effects of functional and dysfunctional conflict on strategic decision making: Resolving a paradox for top management teams. Academy of Management Journal, 39(1), 123-148.

Amason, A. C. (1998). Good and bad conflict in strategic decision making. In Strategic decisions (pp. 51-63). Retrieved from http://link.springer.com/chapter/10.1007/978-1-4615-6195-8_4

Amason, A. C. (2010). TMT Demography, Conflict and (effective) Decision Making: The Key Role of Value Congruence. Academy of Management Proceedings, 2010(1), 1-6. https://doi.org/10.5465/AMBPP.2010.54491815

Amason, A. C., Thompson, K. R., Hochwarter, W. A., \& Harrison, A. W. (1995). Conflict: An important dimension in successful management teams. Organizational Dynamics, 24(2), 20-35.

Avolio, B. J., Jung, D. I., Murry, W., \& Sivasbramaniam, N. (1996). Building highly developed teams: Focusing on shared leadership process, efficacy, trust, and performance. Retrieved from http://psycnet.apa.org/psycinfo/2000-07271-007

Bass, B. M., \& Stogdill, R. M. (1990). Handbook of leadership. Ralph M. Stogdill, A Survey of Theory and Research.

Brown, H. I. (1988). Rationality. New York, NY, US: Routledge.

Brown, M. E., \& Treviño, L. K. (2003). Is values-based leadership ethical leadership. Emerging Perspectives on Values in Organizations, 151-173.

Brown, M. E., Treviño, L. K., \& Harrison, D. A. (2005). Ethical leadership: A social learning perspective for construct development and testing. Organizational Behavior and Human Decision Processes, 97(2), 117-134.

Bruine de Bruin, W., Parker, A. M., \& Fischhoff, B. (2007). Individual differences in adult decision-making competence. Journal of Personality and Social Psychology, 92(5), 938.

Busenitz, L. W., \& Barney, J. B. (1997). Differences between entrepreneurs and managers in large organizations: Biases and heuristics in strategic decision-making. Journal of Business Venturing, 12(1), 9-30.

Carson, J. B., Tesluk, P. E., \& Marrone, J. A. (2007). Shared leadership in teams: An investigation of antecedent conditions and performance. Academy of Management Journal, 50(5), 1217-1234. 
Chang, A., Duck, J., \& Bordia, P. (2006). Understanding the multidimensionality of group development. Small Group Research, 37(4), 327-350.

Ciulla, J. B. (2014). Ethics, the heart of leadership. Retrieved from https://books.google.com/books?hl=en\&lr=\&id=mw9BAAAQBAJ\&oi=fnd\&pg=PP1\&dq=Ethics+the+heart+of+leadership\&ots=gWR6Q5rrg5\&sig=qj5kWoUB6Zg1k7ly6KTGo nXL8vE

Cohen, M. D., March, J. G., \& Olsen, J. P. (1972). A garbage can model of organizational choice. Administrative Science Quarterly, $1-25$.

Dattalo, P. (2008). Determining Sample Size: Balancing Power, Precision, and Practicality. Oxford, New York: Oxford University Press.

Darville, J. (2018) Working Together: decision-making style and conflict in administrative work teams. Gannon University, ProQuest Dissertations Publishing, 2018.

Day, D. V., Zaccaro, S. J., \& Halpin, S. M. (2004). Leader development for transforming organizations: Growing leaders for tomorrow. Routledge.

Dean, J. W., \& Sharfman, M. P. (1993). PROCEDURAL RATIONALITY IN THE STRATEGIC DECISION-MAKING PROCESS*. Journal of Management Studies, 30(4), 587-610.

Drucker, P. (2012). The practice of management. Routledge.

Eisenhardt, Kathleen M., Kahwajy, J. L., \& Bourgeois III, L. J. (1998). Taming interpersonal conflict in strategic choice: How top management teams argue, but still get along. In Strategic decisions (pp. 65-83). Retrieved from http://link.springer.com/chapter/10.1007/978-1-4615-6195-8_5

Eisenhardt, K.M., \& Zbaracki, M. J. (1992). Strategic decision making. Strategic Management Journal, 13(S2), 17-37.

Elbanna, S., \& Child, J. (2007). The Influence of Decision, Environmental and Firm Characteristics on the Rationality of Strategic Decision-Making*. Journal of Management Studies, 44(4), 561-591.

Ensley, M. D., Pearson, A., \& Pearce, C. L. (2003). Top management team process, shared leadership, and new venture performance: a theoretical model and research agenda. Human Resource Management Review, 13(2), 329-346.

Fayol, H. (1909). General and industrial management. Ravenio Books.

Fiedler, F. E. (1995). Reflections by an accidental theorist. The Leadership Quarterly, 6(4), 453-461.

Fisher, B. A., \& Ellis, D. G. (1980). Small group decision making: Communication and the group process. Retrieved from http://www.ulb.tu-darmstadt.de/tocs/179862898.pdf

Forsyth, $\quad$ D. $\quad$ R. $\quad$ (2009). Group $\quad$ dynamics. $\quad$ Retrieved http://books.google.com/books?hl=en\&lr=\&id=RsMNiobZojIC\&oi=fnd\&pg=PR5\&dq=Forsyth+Group+Dynamics\&ots=FFIm rw9JMO\&sig=eW5ScUNIhV3J0_ICf21DdtD8LV8

Gersick, C. J. G. (1988). Time and transition in work teams: Toward a new model of group development. Academy of Management Journal, 31(1), 9-41.

Gigerenzer, G., \& Goldstein, D. G. (1996). Reasoning the fast and frugal way: models of bounded rationality. Psychological Review, 103(4), 650 .

Gigerenzer, G., \& Selten, R. (2001). Rethinking rationality. Bounded Rationality: The Adaptive Toolbox, 1-12.

Graen, G. B., \& Uhl-Bien, M. (1995). Relationship-based approach to leadership: Development of leader-member exchange (LMX) theory of leadership over 25 years: Applying a multi-level multi-domain perspective. The Leadership Quarterly, 6(2), $219-247$.

Hollenbeck, J. R., Ilgen, D. R., Sego, D. J., Hedlund, J., Major, D. A., \& Phillips, J. (1995). Mutlilevel theory of team decision making: Decision performance in teams incorporating distributed expertise. Journal of Applied Psychology, 80(2), 292.

Hutzschenreuter, T., \& Kleindienst, I. (2006). Strategy-process research: what have we learned and what is still to be explored. Journal of Management, 32(5), 673-720.

Huxham, C., \& Vangen, S. (2000). Ambiguity, complexity and dynamics in the membership of collaboration. Human Relations, 53(6), 771-806.

Jehn, K. A. (1994). Enhancing effectiveness: An investigation of advantages and disadvantages of value-based intragroup conflict. International Journal of Conflict Management, 5(3), 223-238.

Jehn, K. A. (1995). A multimethod examination of the benefits and detriments of intragroup conflict. Administrative Science Quarterly, 256-282. 
Jenkins, D. (2012). Global critical leadership: Educating global leaders with critical leadership competencies. Journal of Leadership Studies, 6(2), 95-101.

Kahneman, D. (2003). Maps of bounded rationality: Psychology for behavioral economics. The American Economic Review, 93(5), $1449-1475$.

Kahneman, D. (2011). Thinking, fast and slow. Retrieved from http://books.google.com/books?hl=en\&lr=\&id=SHvzzuCnuv8C\&oi=fnd\&pg=PP2\&dq=Daniel+Kahneman\&ots=NRpiNC6nI $\mathrm{C} \&$ sig=9Powiulrmm--y-Yagr-ChP9iBdY

Kieser, A., \& Koch, U. (2008). Bounded rationality and organizational learning based on rule changes. Management Learning, 39(3), $329-347$.

Kozlowski, S. W., Gully, S. M., Nason, E. R., \& Smith, E. M. (1999). Developing adaptive teams: A theory of compilation and performance across levels and time. Pulakos (Eds.), The Changing Nature of Performance: Implications for Staffing, Motivation, and Development, 240-292.

Lewin, K., \& Gold, M. E. (1999). Group decision and social change. Retrieved from http://psycnet.apa.org/books/10319/010.pdf

Li, H. C., Mirmirani, S., \& Ilacqua, J. A. (2009). Confucius Institutes: Distributed leadership and knowledge sharing in a worldwide network. The Learning Organization, 16(6), 469-482. https://doi.org/10.1108/09696470910993945

McCall, M. W., \& Kaplan, R. E. (1989). Whatever it Takes: The Realities of Managerial Decision Making (2 edition). Englewood Cliffs, N.J: Prentice Hall.

McFarlin, D. B., \& Sweeney, P. D. (1992). Distributive and procedural justice as predictors of satisfaction with personal and organizational outcomes. Academy of Management Journal, 35(3), 626-637.

Pearce, C. L., \& Sims Jr, H. P. (2002). Vertical versus shared leadership as predictors of the effectiveness of change management teams: An examination of aversive, directive, transactional, transformational, and empowering leader behaviors. Group Dynamics: Theory, Research, and Practice, 6(2), 172.

Pearce, C. L., Yoo, Y., \& Alavi, M. (2004). Leadership, social work, and virtual teams. Improving Leadership in Nonprofit Organizations, Edited by Ronald E. Riggio and Sarah Smith Orr, 180-99.

Perry, M. L., Pearce, C. L., \& Sims Jr, H. P. (1999). Empowered selling teams: How shared leadership can contribute to selling team outcomes. Journal of Personal Selling \& Sales Management, 19(3), 35-51.

Pfeffer, J. (1992). Managing with power: Politics and influence in organizations. Retrieved from $\mathrm{http} / /$ /books.google.com/books?hl=en\&lr=\&id=SzKVAwAAQBAJ\&oi=fnd\&pg=PR1\&dq=Power+politics+pfeffer\&ots=38La 3f1wiT\&sig=C90pf6_-SqEWAYHyVQV6r5T_bFE

Rost, J. C. (1993). Leadership for the twenty-first century. Retrieved from http://books.google.com/books?hl=en\&lr=\&id=bM7E8ORH7QC\&oi=fnd\&pg=PR11\&dq=Rost+Leadership+1991\&ots=DJzFnEMlAM\&sig=AP4Hu5K3kECl8w9kpDHZlU Mdhnc

Saint, S., \& Lawson, J. R. (1994). Rules for reaching consensus: a modern approach to decision making. Pfeiffer.

Salas, E., DiazGranados, D., Klein, C., Burke, C. S., Stagl, K. C., Goodwin, G. F., \& Halpin, S. M. (2008). Does team training improve team performance? A meta-analysis. Human Factors: The Journal of the Human Factors and Ergonomics Society, 50(6), 903-933.

Sanfey, A. G., Rilling, J. K., Aronson, J. A., Nystrom, L. E., \& Cohen, J. D. (2003). The neural basis of economic decision-making in the ultimatum game. Science, 300(5626), 1755-1758.

Scholten, L., Van Knippenberg, D., Nijstad, B. A., \& De Dreu, C. K. (2007). Motivated information processing and group decisionmaking: Effects of process accountability on information processing and decision quality. Journal of Experimental Social Psychology, 43(4), 539-552.

Schweiger, D. M., Sandberg, W. R., \& Rechner, P. L. (1989). Experiential effects of dialectical inquiry, devil's advocacy and consensus approaches to strategic decision making. Academy of Management Journal, 32(4), 745-772.

Schwenk, C. R. (1995). Strategic decision making. Journal of Management, 21(3), 471-493.

Scott, S. G., \& Bruce, R. A. (1995). Decision-making style: The development and assessment of a new measure. Educational and Psychological Measurement, 55(5), 818-831.

Simon, H.A. (1997). Models of bounded rationality: Empirically grounded economic reason (Vol. 3). MIT press.

Simon, Herbert A. (1991). Bounded rationality and organizational learning. Organization Science, 2(1), 125-134. 
Simon, Herbert Alexander. (1997). Administrative behavior: a study of decision-making processes in administrative organizations. Simon and Schuster.

Simons, T. L., \& Peterson, R. S. (2000). Task conflict and relationship conflict in top management teams: the pivotal role of intragroup trust. Journal of Applied Psychology, 85(1), 102.

Sowell, T. (1996). Knowledge And Decisions. New York: Basic Books.

Stewart, G. L., \& Manz, C. C. (1995). Leadership for self-managing work teams: A typology and integrative model. Human Relations, 48(7), 747-770.

Sweeney, P. D., \& McFarlin, D. B. (1993). Workers' evaluations of the" ends" and the" means": An examination of four models of distributive and procedural justice. Organizational Behavior and Human Decision Processes, 55(1), 23-40.

Tannenbaum, R., \& Schmidt, W. H. (1973). How To Choose a Leadership Pattern. Harvard Business Review. Retrieved from http://eric.ed.gov/?id=EJ087713

Thomas, K. W. (1988). The conflict-handling modes: Toward more precise theory. Management Communication Quarterly, 1(3), 430-436.

Thompson, L. (2013). Making the Team (5 edition). Boston: Prentice Hall.

To, C., Kilduff, G., Ordóñez, L. D., Schweitzer, M. (2018). We Take More Risks When We Compete Against Rivals. Harvard Business Review.

Trevino, L. K. (1986). Ethical decision making in organizations: A person-situation interactionist model. Academy of Management Review, 11(3), 601-617.

Tuckman, B. W. (1965). Developmental sequence in small groups. Psychological Bulletin, 63(6), 384.

Tuckman, B. W., \& Jensen, M. A. C. (1977). Stages of small-group development revisited. Group \& Organization Management, 2(4), 419-427.

Tversky, A., \& Kahneman, D. (1974). Judgment under uncertainty: Heuristics and biases. Science, 185(4157), 1124-1131.

Ulrich, D. (1998). Intellectual capital= competence x commitment. MIT Sloan Management Review, 39(2), 15.

Vroom, V. H., \& Yetton, P. W. (1973). Leadership and decision-making. University of Pittsburgh Press.

Wheelan, S. A. (1994). Group processes: a developmental perspective. Allyn and Bacon.

Wood, M. S. (2005). Determinants of shared leadership in management teams. International Journal of Leadership Studies, 1(1), 64-85. 